\title{
PARTICULATE MATTER CONCENTRATION AND EMISSION FACTOR IN THREE DIFFERENT LAYING HEN HOUSING SYSTEMS
}

\author{
Annamaria Costa, Marcella Guarino
}

\section{Introduction}

Concentrations and emissions of dust particles from livestock operations are generally determined by the characteristics of the respective housing system, specified e.g. by management, bedding materials, animal species, ventilation, as well as climatic inside and outside conditions [Liao 2001; Takai 1998], feeding practices and feeding type [Costa 2007]. The highest concentration of particulate matter is usually measured in swine and poultry houses [Takai 1998], with appreciable increases in both total and respirable dust [Pedersen 1993] associated with increased animal activity [Haeussermann 2008, Costa 2009].

Substances like dust, micro-organisms and endotoxins, which are also transported as bio-aerosols, are supposed to play a role in the prevalence of respiratory diseases in receptive humans as gathered from occupational health reports on farm workers in animal houses [Parry 1987].

All these kind of bio-aerosols in animal houses are emitted in considerable quantities into the environment by ventilation systems and can consequently also affect the respiratory health of people living close to livestock enterprises [IPCC 2005] and since these particles can carry diseases (for example, Newcastle disease), environmental conditions in enclosed laying hens houses must be strictly controlled [Carpenter 1986].

The aim of this article was to evaluate dust concentration and its emission from three different types of laying hens houses which are fairly widespread in Italian poultry farms, through a long-term monitoring research.

Paper received 17.12.2008; accepted 21.07.2009

Annamaria Costa, Marcella Guarino, Università degli Studi di Milano, Department of Veterinary and Technological Sciences for Food Safety, Faculty of Veterinary Medicine, via Celoria, 10, 20133 Milan, Italy.

Corresponding author: annamaria.costa@unimi.it

\section{Materials and methods}

\subsection{Farms location}

The measurements were taken in three commercial laying hen units located in Northern Italy, near Cremona and Brescia. The monitored techniques were:

1. Battery system with pit under cages and a scraper to remove manure (BSP)

2. Aviary system house (ASH)

3. Vertical tiered cages with manure belts with forced air drying (VTC).

Battery system with pit under cages and a scraper to remove manure (BSP).

The house, with 11.000 hens lodged, is $14 \mathrm{~m}$ wide $\mathrm{x}$ $70 \mathrm{~m}$ long. The house is ventilated by 4 fans of $1.16 \mathrm{~m}$ of diameter, positioned on one of the two longitudinal walls, the maximum ventilation rate is $42000 \mathrm{~m}^{3} \mathrm{~h}^{-1}$ for each fan.

The air is collected from the roof, insulated by polystyrene sheets, enters the house through a continuous longitudinal ridge chimney. The ventilation program is computer controlled and based on thermostatic regulation (the first group of fans are active for the minimum ventilation level, when temperature is higher than $15.4{ }^{\circ} \mathrm{C}$, the second group switched on when temperature inside the barn was equal or greater than $22^{\circ} \mathrm{C}$.

\section{Aviary system house (ASH).}

The house, with 7500 hens lodged is $14 \mathrm{~m}$ wide $\mathrm{x}$ $70 \mathrm{~m}$ long, is ventilated by 4 fans of $1.16 \mathrm{~m}$ of diameter, positioned on one of the two longitudinal walls, the maximum ventilation rate is $42000 \mathrm{~m}^{3} \mathrm{~h}^{-3}$ for each fan.

As in the previous housing system, the air is collected from the roof, insulated by polystyrene sheets, enters the house through a continuous longitudinal ridge chimney.

The ventilation strategy is computer controlled and based on thermostatic regulation (the first group of fans are active for the minimum ventilation level, 


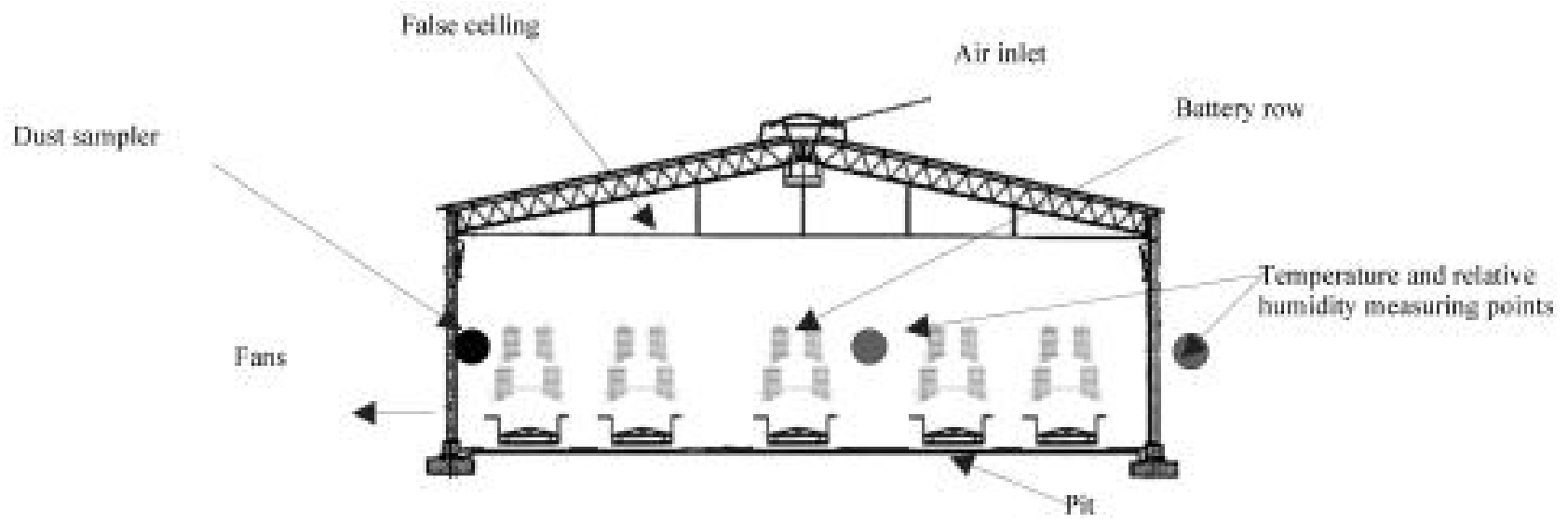

Fig. 1 - Cross section of the battery system house

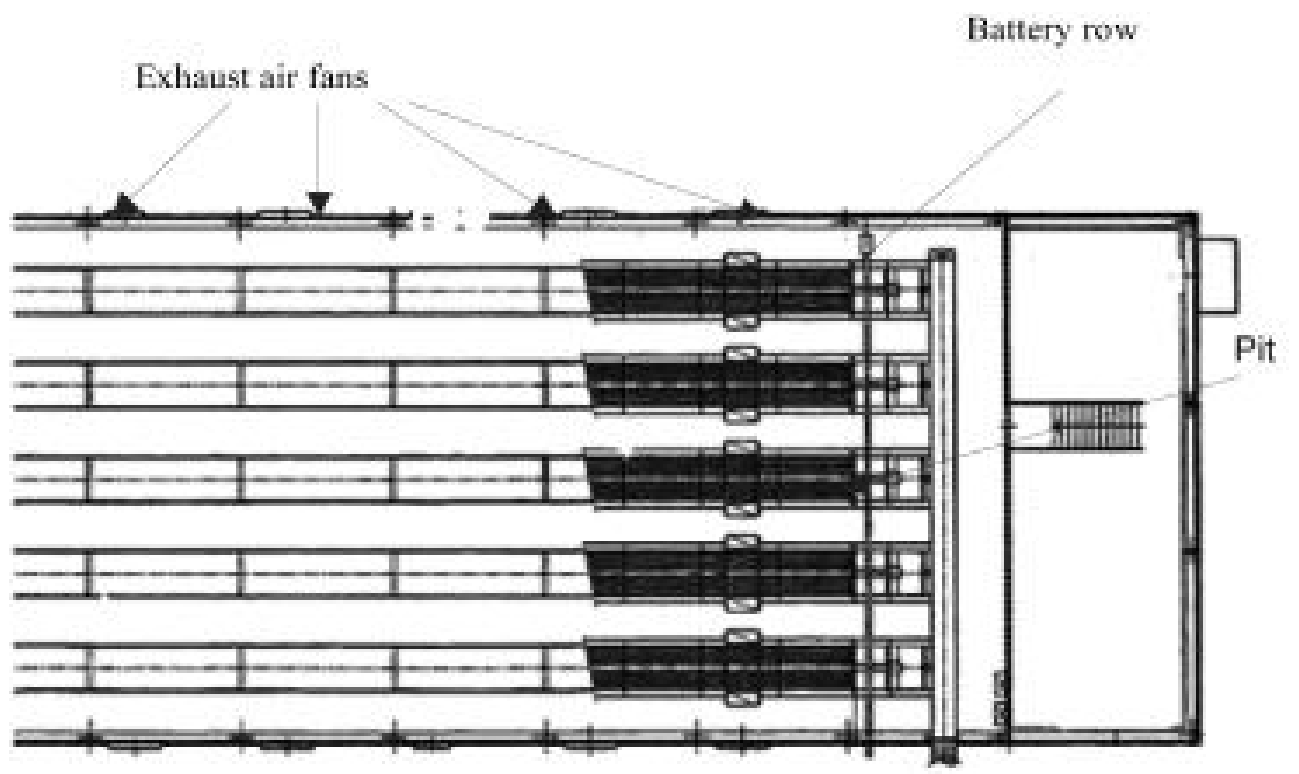

Fig. 2 - Top view of the battery system house.

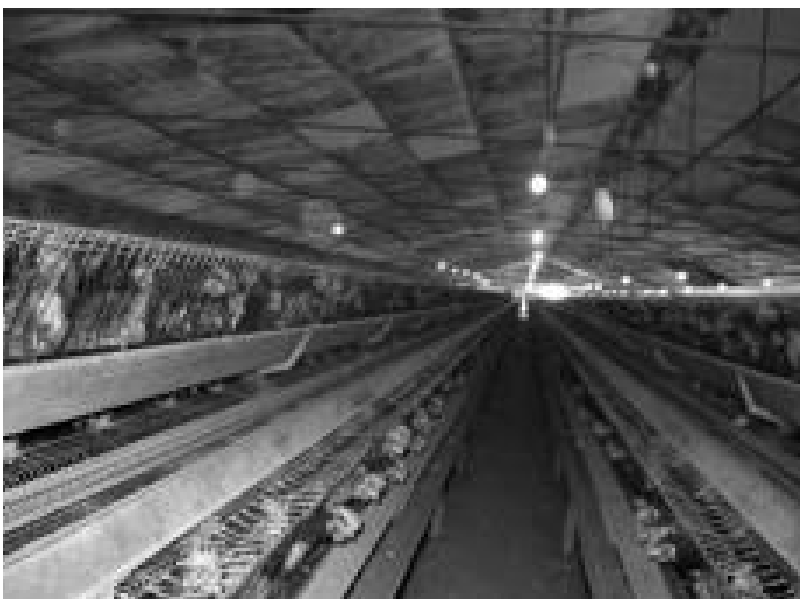

Fig. 3 - The battery system hens house.

when temperature is higher than $15.4{ }^{\circ} \mathrm{C}$, the following groups are switched on when temperature inside the barn reaches $22^{\circ} \mathrm{C}$.
In this house hens are reared on the litter and flat decks at different levels. The nest for eggs deposition is located in the middle of the room. This housing type is endorsed by EU rules on animal welfare.

Vertical tiered cages with manure belts with forced air drying (VTC).

This hens house has 8 rows of 6-tier cages with 22000 hens lodged. The droppings are collected on the manure-belts under each tier and they are dried by air jet.

The manure drying system is designed so that maximum air speed is at bird level, no higher than 2.0-2.5 $\mathrm{m} \mathrm{s}^{-1}$, to avoid disturbing the birds in the winter months.

The house has 8 fans on the longitudinal wall, with a maximum ventilation rate of $32000 \mathrm{~m}^{3} \mathrm{~h}^{-1}$ each, the ventilation program is always running.

The manure is discharged every 3-4 days to sheltered external storage. 


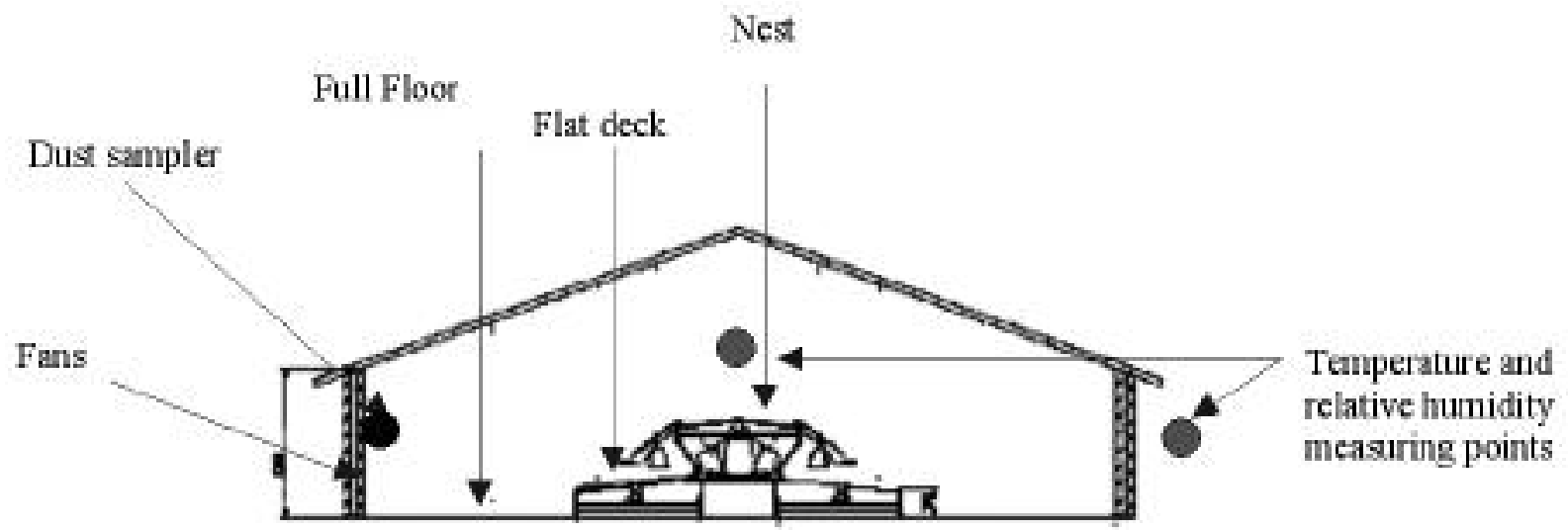

Fig. 4 - Cross section of the aviary system house.

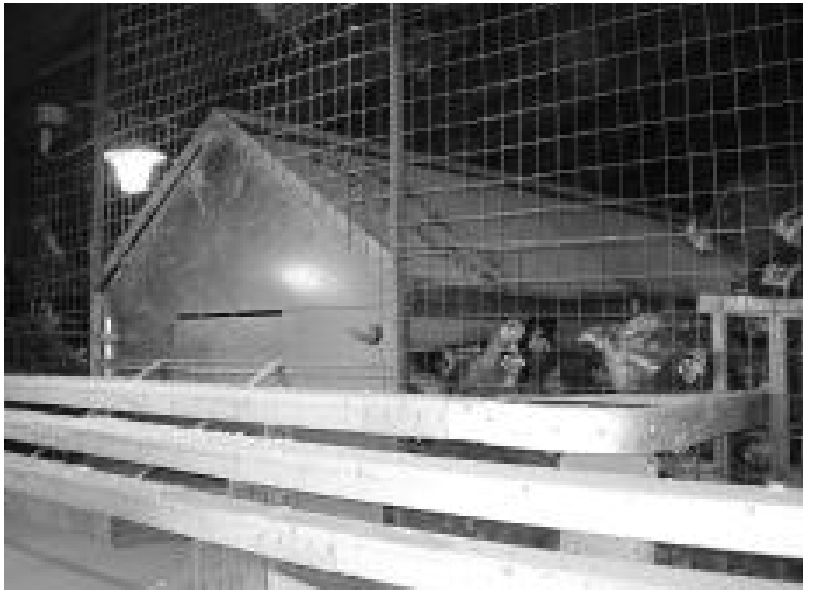

Fig. 5 - The nest in the middle of the aviary system house

The house has a tunnel ventilation system thermostatically controlled on a 4 step basis, with air inlets on the opposite wall of the one with fans. This housing system type is classified as a BAT (Best Available Techniques) for its low environmental impact [ILFBREF 2003].

\subsection{Dust concentration measuring equipment}

In each of these facilities, the $\mathrm{PM}_{10}$ concentration was continuously monitored, with an acquisition interval time of one minute, using calibrated scatter light photometers (accuracy: $\pm 3 \mu \mathrm{g} \mathrm{m}^{-3}$; EPAM 5000, HAZ-Dust; Environmental Devices Corporation, Plaistow, $\mathrm{NH}$ ).

In order to ensure isokinetic sampling conditions, the dust measuring instrument inside the buildings was positioned in such a way that the airflow rate, checked with an hot wire anemometer, was in general less than $0.5 \mathrm{~m} \mathrm{~s}^{-1}$, as described by Haeussermann [2008] and Costa [2009].

The same instrument was also used in order to collect $\mathrm{PM}_{10}$ through traditional gravimetric technique. This procedure was performed to adjust the particulate matter specific gravity of bio aerosol, that is typical and specific for every animal house.

The mean value of dust amount collected on the membranes was utilized as a correction factor to be applied to the continuously collected data. $\mathrm{PM}_{10}$ was collected once in each housing type every 45 monitoring days, using polytetrafluoroethylene (PTFE) membranes (47 $\mathrm{mm}$ of diameter and $2.0 \mu \mathrm{m}$ of pore size, $\mathrm{SKC}$ ).



Fig. 6 - Cross section of the vertical tiered cages with manure belts with forced air drying house. 


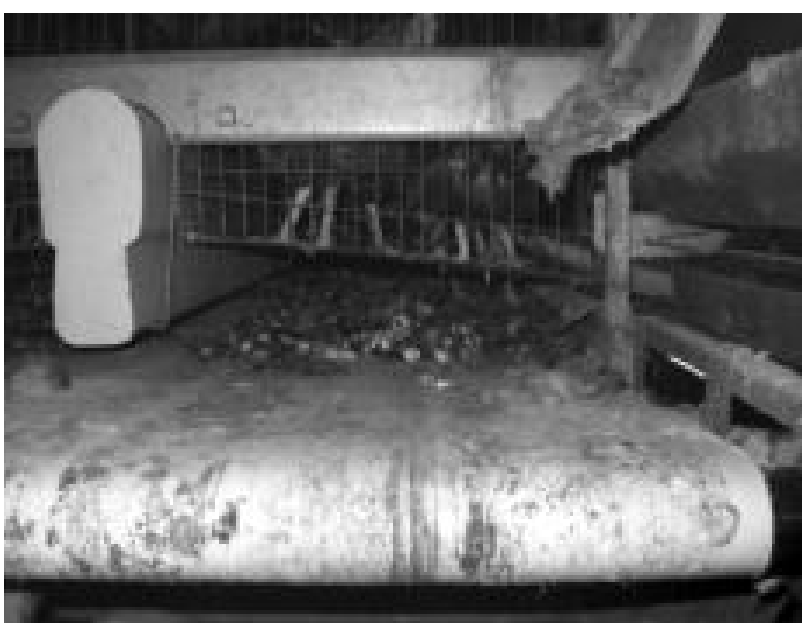

Fig. 7 - The ventilated belt for dropping drying and removal in the vertical tiered cages with manure belts with forced air drying house.

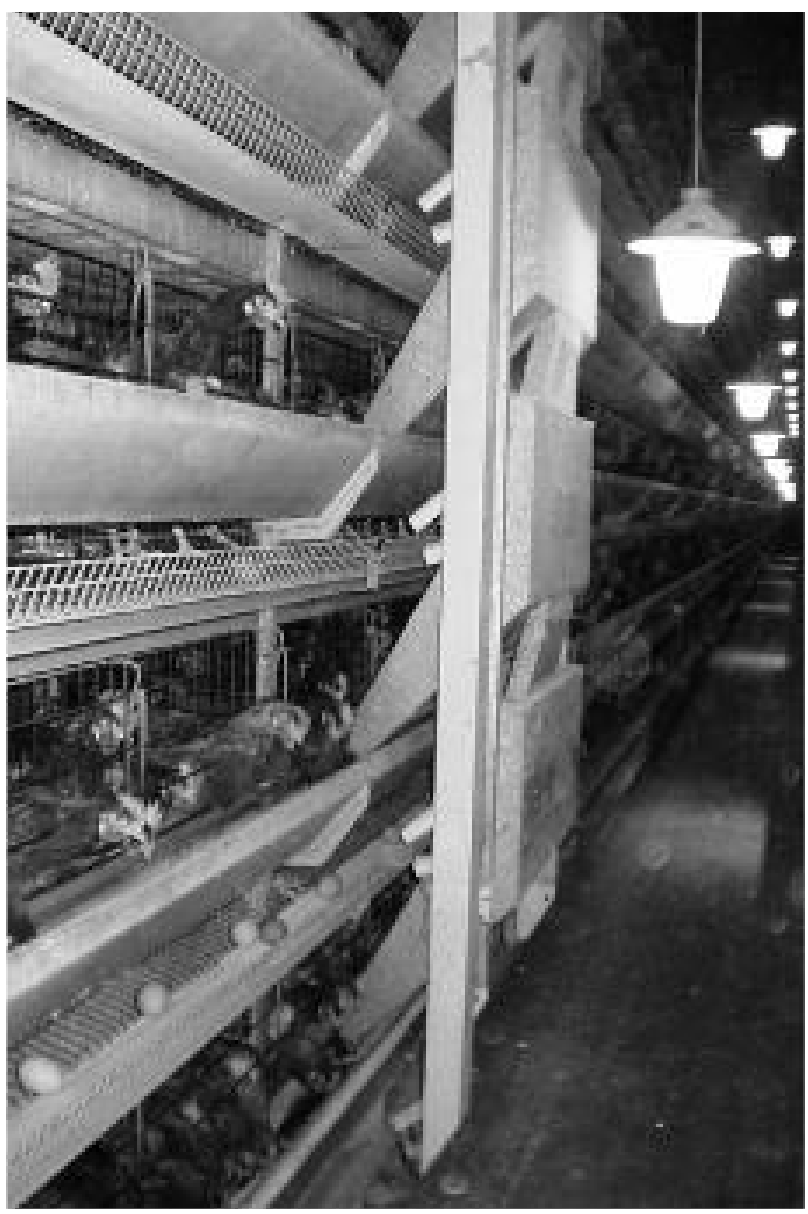

Fig. 8 - Feed administration system in the ventilated belt hens house.

\begin{tabular}{|l|c|c|}
\hline Housing type & Correction factor & St. Dev. \\
\hline VTC & 0.87 & 0.003 \\
\hline ASH & 0.94 & 0.001 \\
\hline BSP & 1.02 & 0.001 \\
\hline
\end{tabular}

TABLE 1 - Correction factor applied to on-line measured data.

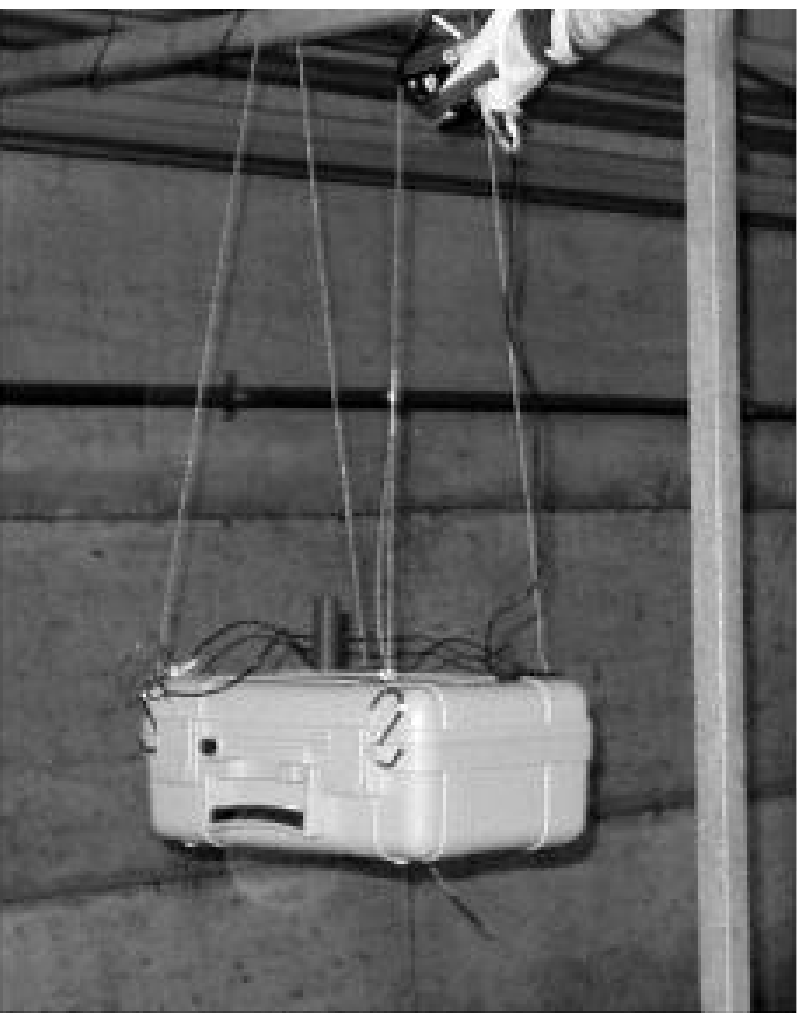

Fig. 9 - Dust sampler in the in the vertical tiered cages with manure belts with forced air drying house.

The membranes were weighed using a microbalance $(0.000001 \mathrm{~g})$ in a controlled humidity room before and after dust collection. The filters were dried in an oven at $100^{\circ} \mathrm{C}$ for four hour before weighing. Table 1 reports the correction factors for dust measurements obtained during the monitoring periods.

\subsection{Total Suspended Particles (TSP)}

and fine dust sampling, in the aviary system house

TSP (Total Suspended Particles) and fine dust measurements were exclusively performed in the ASH house, since this hens house will be one of the most spread housing system for poultry rearing, because of the application of the EC Directive on Poultry Welfare [2002/4/Ce], and also for the considerable particulate matter high concentration measured in the preliminary monitoring phase in this housing system type. For this purpose, a sampling station was set up, consisting of a pump with a counter-positioned piston and a constant, pre-set airflow rate $\left(8.851 \mathrm{~min}^{-1}\right)$, connected to a system that controlled and recorded the volume of the air pumped by the instrument.

The station was connected to a sampling instrument (Sioutas, Cascade Impactor) to separate and collect airborne particles in five size ranges: TSP, particles smaller than $2.5 \mu \mathrm{m}$, particles in the range from 1.0 to $2.5 \mu \mathrm{m}$, from 0.50 to $1.0 \mu \mathrm{m}$, from 0.25 to 0.50 $\mu \mathrm{m}$, and particles smaller than $0.25 \mu \mathrm{m}$.

Samples were collected from 9.00 to 17.00 to study 


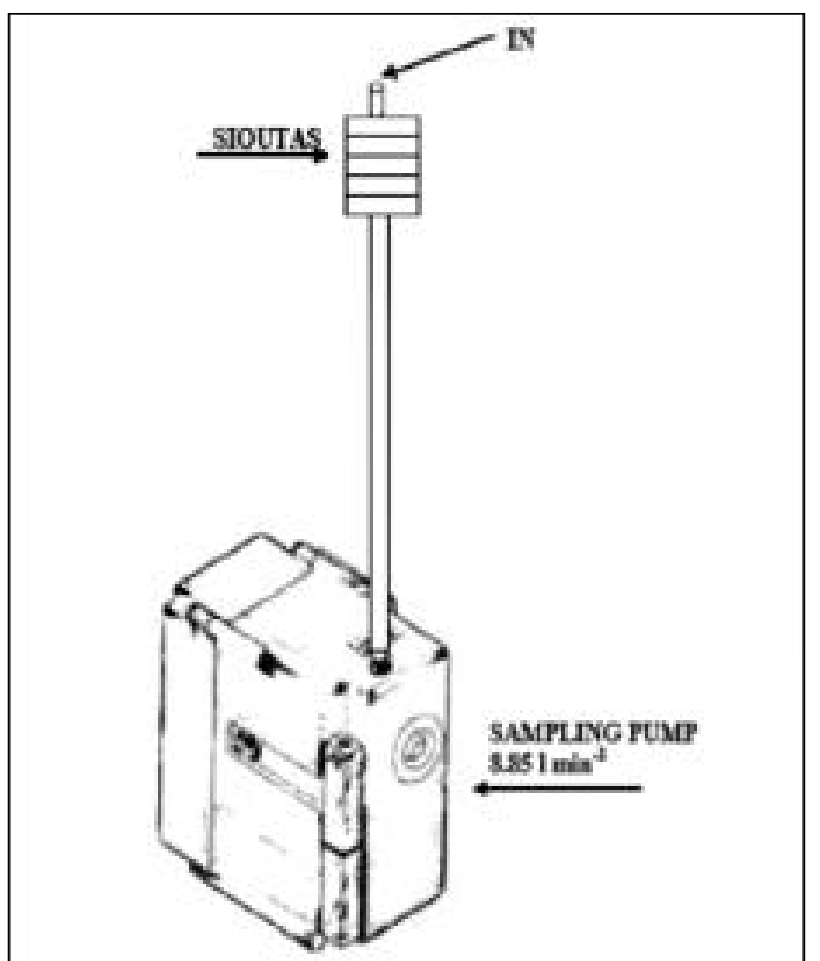

Fig. $\quad 10$ - Scheme of the TSP and fine dust sampler station (SIOUTAS connected to a pump) in the aviary system house.

the amount of fine dust inhaled by operators during a working day. Filters used in this part of the study were 37-mm PTFE Teflon, prepared as described above for $\mathrm{PM}_{10}$ evaluation.

\subsection{Ventilation rate and environmental parameters}

The ventilation rate was monitored by recording the number of active fans, the air flow rate was measured for each fan in 9 different positions of its surface using a hot wire anemometer (BSV 105, LSI, Settala,
Milano). Measurements were taken for each monitoring cycle (six times per year) for each ventilation step. The mean air flow rate was compared to the nominal ventilation rate to calculate the effective ventilation rate for each fan and the measurement error.

The use of the hot wire anemometer allows an accuracy ranging from to 0.5 to $25 \%$ in checking the effective ventilation rate [Scholtens 1994; Janssen 1990], in our study the measurement accuracy was calculated to be $5 \%$.

The temperature and relative humidity were monitored constantly both inside and outside the houses, with dataloggers (Babuc M, LSI, Settala, Milano).

\subsection{Emission rate calculation}

Emission rate was calculated as the multiplication of pollutant concentration with the ventilation rate recorded in the same minute, as reported in the following equation. Data presented in the results are the mean values of the single emission rates calculated for every minute of the monitoring procedures.

\section{$\mathrm{Ei}=\mathrm{Ci} \times \mathrm{Vi}$}

Equation 1. Pollutant emission calculation Where:

$\mathrm{Ei}=$ Pollutant Emission at time i,

$\mathrm{Ci}=$ Pollutant Concentration at time $\mathrm{i}$

$\mathrm{Vi}=$ Ventilation rate at time $\mathrm{i}$

$\mathrm{i}=$ time (in minute)

\section{Results and discussion}

\subsection{Environmental parameters and particulate matter}

In table 2 , the results of the yearly monitoring in the three laying hens houses are shown, subdivided in

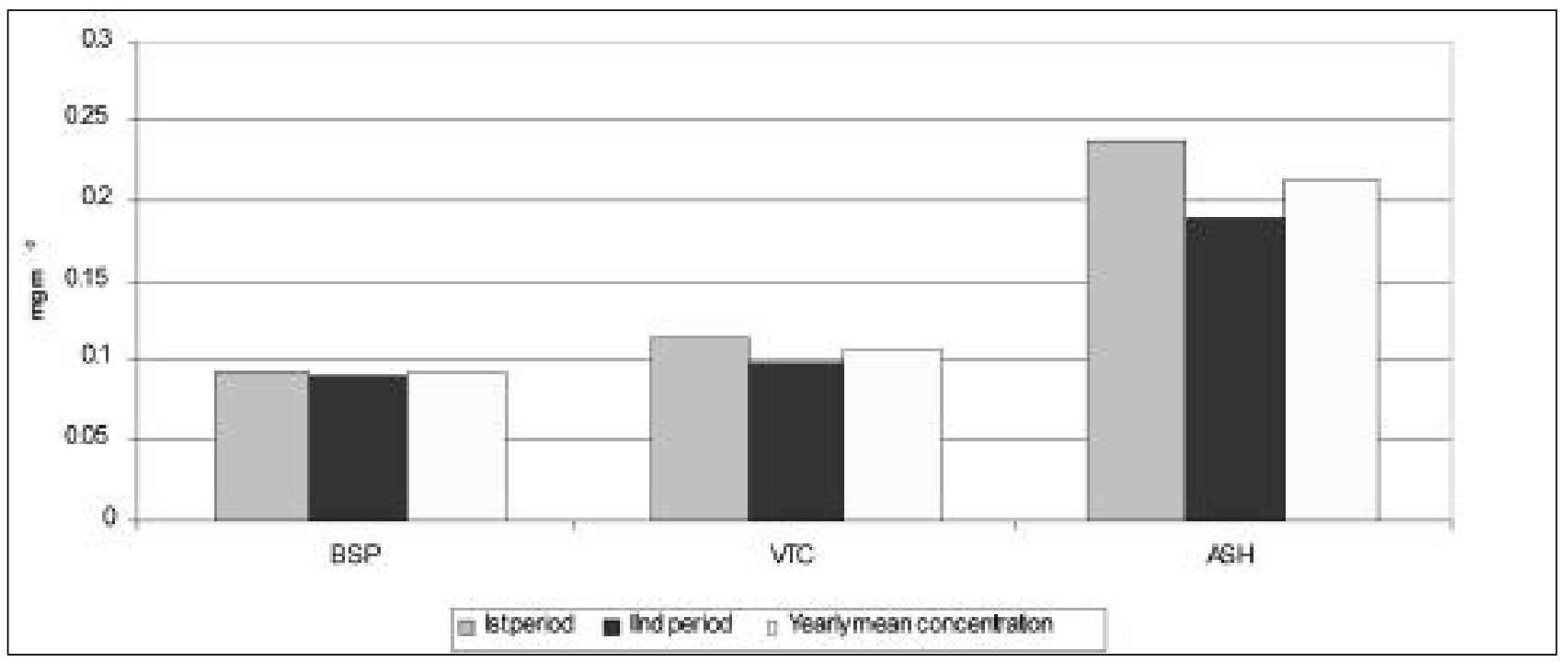

Fig. $11-\mathrm{PM}_{10}$ concentration in the three hens houses. 


\begin{tabular}{|c|c|c|c|c|c|c|c|}
\hline \multirow[t]{2}{*}{ Building type } & & \multicolumn{2}{|c|}{$\overline{\mathrm{BSP}}$} & \multicolumn{2}{|c|}{$\overrightarrow{\mathrm{ASH}}$} & \multicolumn{2}{|c|}{$\overline{\mathrm{VTC}}$} \\
\hline & Monitoring period & $\overline{\text { Period } \mathrm{I}^{-}}$ & Period II & Period I & Period III & $\bar{P}$ Period I ${ }^{-}$ & Period Iİ \\
\hline \multirow{3}{*}{$\begin{array}{l}\text { Structuent } \\
\text { characieristics }\end{array}$} & Ventilation syslem & \multicolumn{2}{|c|}{$\begin{array}{l}4 \text { Exhoust fins in one of the two } \\
\text { the kegitudinat walls }\end{array}$} & \multicolumn{2}{|c|}{$\begin{array}{l}4 \text { Exhouse fans in one of the } \\
\text { two the longitudinal walls }\end{array}$} & \multicolumn{2}{|c|}{$\begin{array}{l}\text { 8. Fxtraust fans in one of the two the } \\
\text { kegitudinal walls }\end{array}$} \\
\hline & Number of snimals & \multicolumn{2}{|l|}{11.000} & \multicolumn{2}{|l|}{7500} & \multicolumn{2}{|l|}{22000} \\
\hline & $\begin{array}{l}\text { Dropsing removal } \\
\text { system }\end{array}$ & \multicolumn{2}{|c|}{$\begin{array}{l}\text { Dip pit with a scraper to remove } \\
\text { droppings }\end{array}$} & \multicolumn{2}{|c|}{$\begin{array}{l}\text { Litter, a belt in front of the } \\
\text { nest ressoves druppilazs }\end{array}$} & \multicolumn{2}{|c|}{$\begin{array}{l}\text { Manure belts under cages with } \\
\text { forced air drying }\end{array}$} \\
\hline \multirow[t]{2}{*}{$\begin{array}{l}\text { Inisrmal } \\
\text { Microclimate }\end{array}$} & $\begin{array}{l}\text { Temperature } \mathrm{C} \text { : } \\
\text { (min; max) }\end{array}$ & $\begin{array}{c}18.65 \\
\{11: 24: 25 \times 0\}\end{array}$ & $\begin{array}{c}19.31 \\
\langle 13.24: 27.32\rangle\end{array}$ & $\begin{array}{c}14.58 \\
(5.32 ; 2521)\end{array}$ & $\begin{array}{c}21.42 \\
(15,47 ; 2 \times 59)\end{array}$ & $\begin{array}{c}21.24 \\
(18.0 n ; 2263)\end{array}$ & $\begin{array}{c}2006 \\
(17 \geq 5 ; 23,+6)\end{array}$ \\
\hline & $\begin{array}{l}\text { Relative Humidiy \% } \\
\text { (min: max) }\end{array}$ & $\begin{array}{c}55 \\
(24,58)\end{array}$ & $\begin{array}{c}56 \\
{[27,86]}\end{array}$ & $\begin{array}{c}62 \\
128,97)\end{array}$ & $\begin{array}{c}46 \\
(32 ; 58)\end{array}$ & $\begin{array}{c}55 \\
(28.74)\end{array}$ & $\begin{array}{c}50 \\
(42: 67)\end{array}$ \\
\hline \multirow[t]{2}{*}{$\begin{array}{l}\text { Extermal } \\
\text { Microclimate }\end{array}$} & $\begin{array}{l}\text { Mean Temperature }{ }^{2} \mathrm{C} \\
\text { (min; max) }\end{array}$ & $\begin{array}{c}12.41 \\
(-1: 29)\end{array}$ & $\begin{array}{c}19.34 \\
(62: 32.3)\end{array}$ & $\begin{array}{c}12.4) \\
(-1: 29\}\end{array}$ & $\begin{array}{c}19.34 \\
10.2: 32.33\end{array}$ & $\begin{array}{l}14.9 \mid \\
\mid-3: 289\end{array}$ & $\begin{array}{c}18.11 \\
09.3: 36.71\end{array}$ \\
\hline & $\begin{array}{l}\text { Relative Humidity }{ }^{6} \\
\text { (min;max) }\end{array}$ & $\begin{array}{c}66 \\
125: 99]\end{array}$ & $\begin{array}{c}59 \\
{[25: 93]}\end{array}$ & $\begin{array}{c}66 \\
{[25 ; 99]}\end{array}$ & $\begin{array}{c}55 \\
(25: 93)\end{array}$ & $\begin{array}{c}53 \\
(25 ; 78)\end{array}$ & $\begin{array}{c}53 \\
(38 ; 89)\end{array}$ \\
\hline Ventilation raic & $\begin{array}{l}\text { Mean of the period } \\
m^{2} h^{\prime}\end{array}$ & 59481 & 65498 & 15892 & 72752 & 13672 & 22227 \\
\hline \multirow{4}{*}{$\begin{array}{l}\mathrm{PM}_{n} \\
\text { (ocrected by } \\
\text { groimutric } \\
\text { mothod) }\end{array}$} & $\begin{array}{l}\text { Mean cenceniration of } \\
\text { the period, mg m }\end{array}$ & 0.095 & 0.093 & 0238 & $\theta, 1 \mathrm{Z}$ & 9,110 & 0.09 \\
\hline & $\begin{array}{l}\text { Yearly weal } \\
\text { conccutration, } \mathrm{mg} \mathrm{m}^{-3}\end{array}$ & \multicolumn{2}{|c|}{0.094} & \multicolumn{2}{|c|}{$\frac{1}{0.15}$} & \multicolumn{2}{|c|}{$6.10 \mathrm{~s}$} \\
\hline & $\begin{array}{l}\text { Mean enesioe of the } \\
\text { period, mg } h^{-1} \text { ben " }\end{array}$ & 0276 & 0390 & 0.600 & 186 & 9.969 & 0.094 \\
\hline & $\begin{array}{l}\text { Yearly mean entissben } \\
\text { factor, } \mathrm{mg}^{-4} \text { hen }^{-4}\end{array}$ & \multicolumn{2}{|c|}{0.43} & \multicolumn{2}{|c|}{1230} & \multicolumn{2}{|c|}{$\frac{1}{0.081}$} \\
\hline
\end{tabular}

Legend:

Period I: November $2006-$ Mas 2007

Period II: June 2007 - November 2007

TABLE 2 - Structural characteristics, environmental parameters and dust emission factors in the three laying hens houses.

the periods between November 2006 and May 2007 (I period), and June and November 2007 (II Period). In this table, data related to on-line $\mathrm{PM}_{10}$ concentration is corrected by gravimetric technique.

\section{2 $\mathrm{PM}_{10}$ Concentration}

$\mathrm{PM}_{10}$ concentration, see Fig. 11, was remarkably higher in the ASH with an average concentration of $0.215 \mathrm{mg} \mathrm{m}^{-3}$ vs $0.094 \mathrm{mg} \mathrm{m}^{-3}$ of the BSP and vs $0.108 \mathrm{mg} \mathrm{m}^{-3}$ of the VTC. In the ASH, the ventilation rate was considerably higher in the second period, and, as expected, the dust mean concentration resulted lower $\left(0.238 \mathrm{mg} \mathrm{m}^{-3}\right.$ vs $\left.0.192 \mathrm{mg} \mathrm{m}^{-3}\right)$. The high dust concentration was mainly due on the particles released by the litter and on the dried droppings on the floor re-suspended by animals. In fact, in this housing system, hens are free to move and to fly in the building, provoking the re-suspension of dust, according to studies reported by the Best Reference Document [2003].

During all the monitoring year, the daily trend of particulate matter concentration, in the three houses, reached the maximum values in the early and central hours of the day, an example of the daily pattern of $\mathrm{PM}_{10}$ mean concentration in the ASH house is presented in Figure 12.

These peaks in dust concentration were related to an increase in animal activity occurring for feeding time and egg deposition, and to the farmers activity (animals' inspection, eggs manual picking up, droppings removal) during the morning and in the central part of the day. During the afternoon (between 13.00 and 17.00), dust concentration was usually low and uniform, in correspondence with the absence of men's and animals' activity (see Fig. 12 and, more in details the Fig. 13).

Figure 13 shows the $\mathrm{PM}_{10}$ average hourly ranges during the day, in absolute value, the highest hourly ranges, or variations, in $\mathrm{PM}_{10}$ concentration happened between 11.00 and 12.00 with $1.321 \mathrm{mg} \mathrm{m}^{-3}$ (see Graphic in Fig. 13) and between 12.00 and 13.00, with an average increase in $\mathrm{PM}_{10}$ concentration reaching the value of $1.409 \mathrm{mg} \mathrm{m}^{-3}$. 


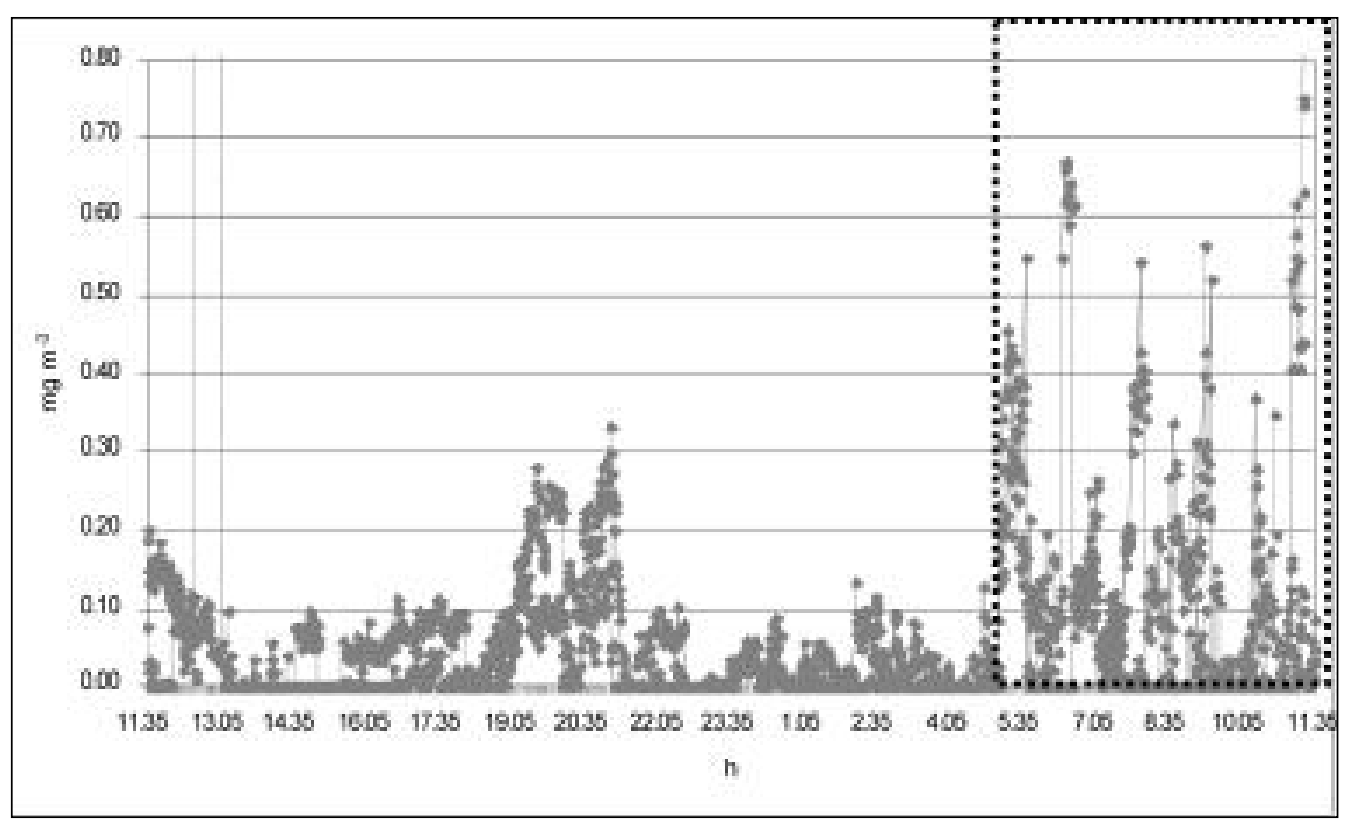

Fig. 12 - Example of diurnal pattern of $\mathrm{PM}_{10}$ mean concentration in the $\mathrm{ASH}$, in the bounded zone, particulate matter concentration peaks occurring in the morning.

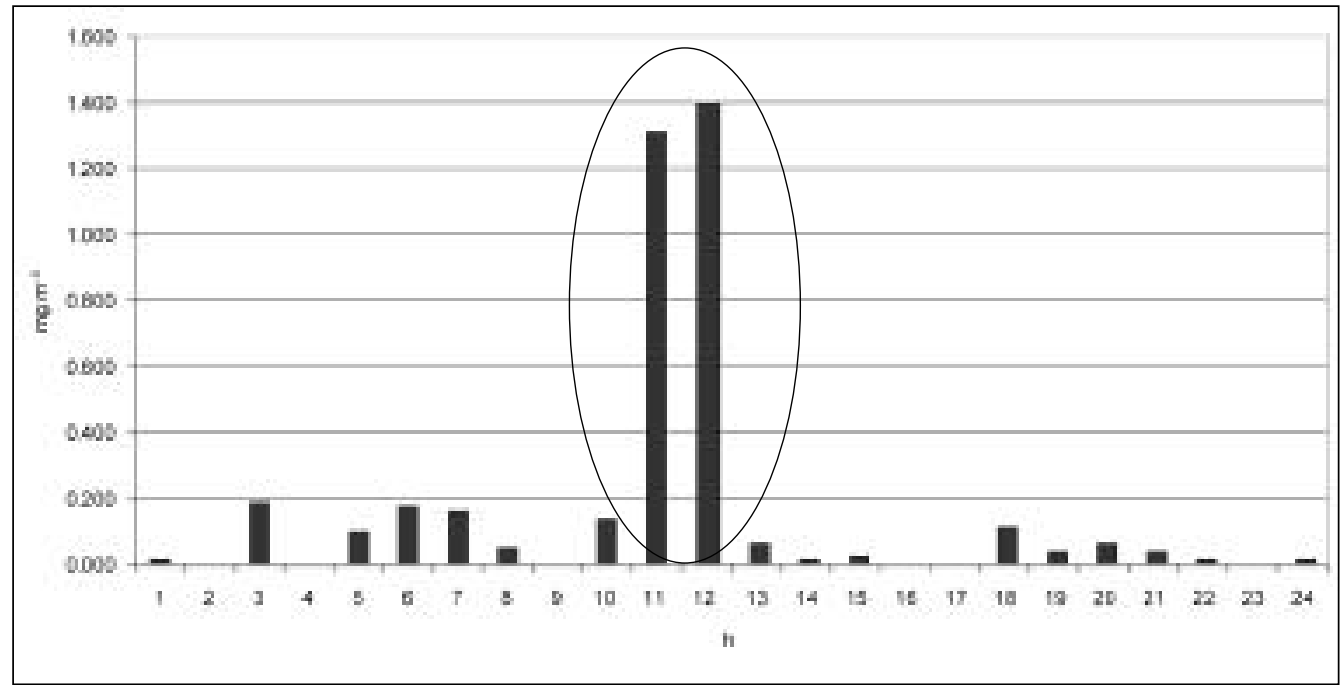

Fig. 13 - Hourly mean range (in absolute values) of $\mathrm{PM}_{10}$ concentration during the 24 hours in the aviary system house.

\subsection{PM $M_{10}$ Emission}

The average emission factors calculated on yearly basis were $0.081 \mathrm{mg} \mathrm{h}^{-3} \mathrm{hen}^{-1}$ for the VTC house, $0.433 \mathrm{mg} \mathrm{h}^{-3} \mathrm{hen}^{-1}$ for the BSP, and $1.230 \mathrm{mg} \mathrm{h}^{-3} \mathrm{hen}^{-1}$ for the ASH house (see fig. 14).

Values measured in the two first housing systems are however generally lower than those available in literature, for example, Zhao [2005] found an emission factor of $0.830 \mathrm{mg} \mathrm{h}^{-1} \mathrm{hen}^{-1}$ in similar housing systems for laying hens.

The lower dust concentration measured in VTC can be attributed to the farmer's practice of restricting the ventilation time for belt droppings (4 hours a day, during the night): probably, the moisture of droppings on the belt worked as a "capturing surface" of the dust particles, reducing the level particulate matter in the environment and its re-suspension, in agreement with a study conducted by Fabbri [2007].

Yearly mean ventilation rates were similar in the BSP and in the ASH with mean values of $5.7 \mathrm{~m}^{3} \mathrm{~h}^{-1}$ hen $^{-1}$ vs $6.1 \mathrm{~m}^{3} \mathrm{~h}^{-1}$ hen $^{-1}$ respectively, while the mean ventilation rate measured in the VTC house was very low, $0.8 \mathrm{~m}^{3} \mathrm{~h}^{-1} \mathrm{hen}^{-1}$ for.

In this paper, the ventilation rate, the dust yearly mean concentration and its emission are provided on yearly basis, with the aim to compare the results to the dust emission factors definition reported by Emission Inventories. 


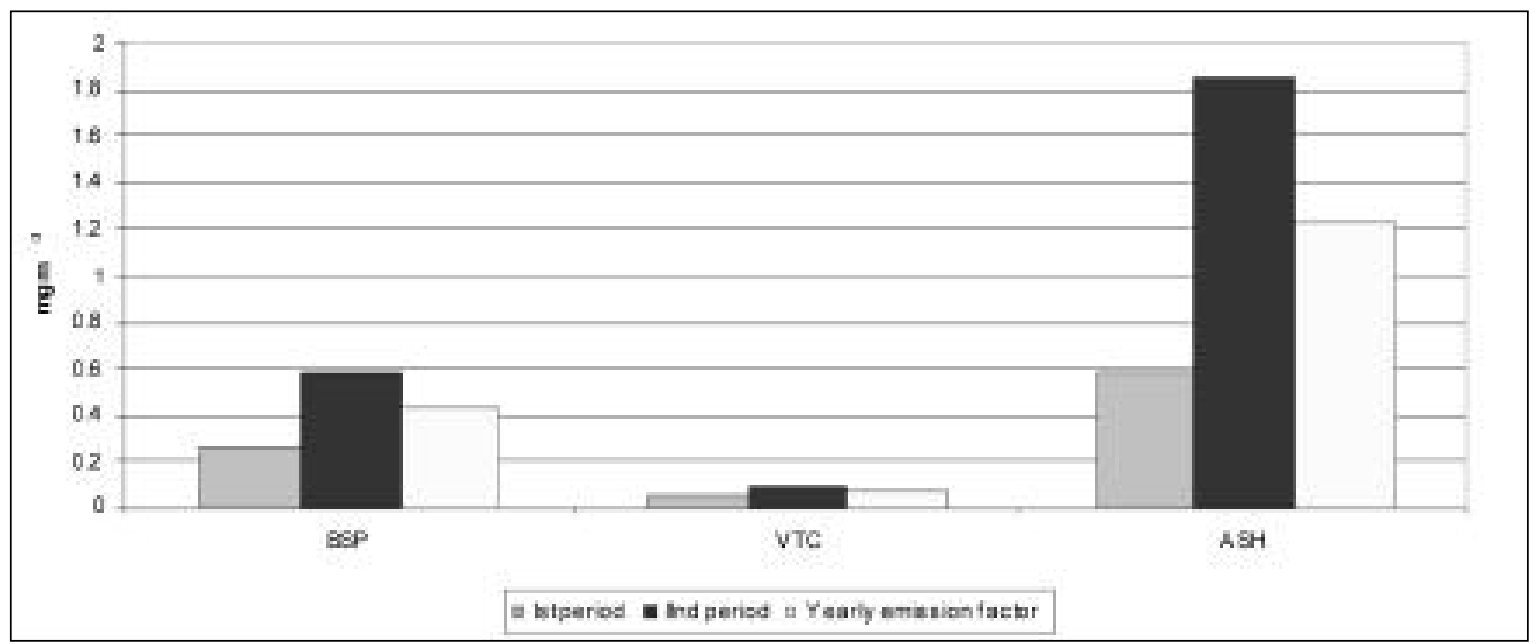

Fig. $14-\mathrm{PM}_{10}$ emission from the laying hen housing systems.

\subsection{TSP and fine dust sampling, in the aviary system house}

Table 3 shortly reassumes the quantitative subdivision of TSP and thin particulate matter concentrations in the ASH house.

Data related to particle size class concentration were not significantly different during the sampling days, the amounts of $\mathrm{PM}_{0.25}$ and $\mathrm{PM}_{2.5}$ collected are a consistent portion of the dust sampled in the aviary system house.

TSP concentration was $0.444 \mathrm{mg} \mathrm{m}^{-3}$ and its the emission rate was calculated in $4.29 \mathrm{mg} \mathrm{h}^{-1}$ hen $^{-1}$ or $30.29 \mathrm{~g} \mathrm{~d}^{-1}$ per LU. Limited references are available for TSP concentration and emission from an aviary system housing, Wathes et al. [1998] measured a TSP emission factor ranging from $20.4 \mathrm{~g} \mathrm{~d}^{-1}$ per LU to $33.6 \mathrm{~g} \mathrm{~d}^{-1}$ per LU, in a perchery, that represents a housing type similar to the aviary system.

The results obtained in this study, when linked to the researches in industrial disease, highlight the existence of a severe working environment for men and animals: in studies conducted by Wang [1998] it was demonstrated that dust inhaled in animal houses can affect the concentration of $\beta$ interleukin altering the respiratory functionality in human.

In reference to Table 3, and, considering that a human being, with a normal respiratory frequency, can breath from 6 to $81 \mathrm{~min}^{-3}$ of air, in an atmosphere

\begin{tabular}{|c|c|}
\hline $\begin{array}{c}\text { Particle size class } \\
\text { (micron) }\end{array}$ & $\begin{array}{c}\text { Dust collected on filter } \\
\mathrm{mg} \mathrm{m}^{-3}\end{array}$ \\
\hline 0.25 & 0.019 \\
\hline 0.50 & 0.018 \\
\hline 1.00 & 0.007 \\
\hline 2.50 & 0.032 \\
\hline TSP & 0.444 \\
\hline
\end{tabular}

TABLE 3 - TSP and fine dust particle size measured in the aviary system house. with a $\mathrm{PM}_{2.5}$ concentration similar to that one observed in this study, one could inhale, at a breathing rate of $61 \mathrm{~min}^{-3}$, up to $0.012 \mathrm{mg} \mathrm{h}^{-3}$, or $0.092 \mathrm{mg}$ of fine dust during 8 working hours.

This aspect takes even more importance since particles smaller than $5 \mu \mathrm{m}$ are rarely expelled from the lungs, causing allergic and inflammatory reactions [Rylander 1986; Thelin 1984].

From a study lead by Lagorio [2003], a strong association between dust concentration variation, more than dust high concentration itself, and damages to the heart function was found.

Balduzzi [2003] singled out a tight correlation between sanitary risk (heart attack and pathologies in general) and the increase in dust concentration, stating that a variation of $10 \mu \mathrm{g} \mathrm{m}^{-3}$ of $\mathrm{PM}_{10}$ concentration corresponds to the $0.6 \%$ increased mortality in human.

The remarkable variation of $\mathrm{PM}_{10}$ concentration that usually took place in the ASH during the morning (up to $1.409 \mathrm{mg} \mathrm{m}^{-3}$ ), mainly in dependence of the litter and for the free movement of animals in the house that induce the re-suspension of dust, highlights how this hens housing system cannot guarantee a healthy working environment for operators.

\section{Conclusions}

- $\mathrm{PM}_{10}$ concentration was $0.215 \mathrm{mg} \mathrm{m}^{-3}$ in the ASH, $0.108 \mathrm{mg} \mathrm{m}^{-3}$ in the VTC and $94 \mu \mathrm{g} \mathrm{m}^{-3}$ in the BSP

- $\mathrm{PM}_{10}$ emission factor was $0.433 \mathrm{mg} \mathrm{h}^{-1} \mathrm{hen}^{-1}$ for the BSP, $0.081 \mathrm{mg} \mathrm{h}^{-1} \mathrm{hen}^{-1}$ for VTC, $1.230 \mathrm{mg} \mathrm{h}^{-1}$ hen $^{-1}$ for the ASH.

- The ASH (Aviary system house) showed the highest $\mathrm{PM}_{10}$ emission with peaks during the morning, together with the increased animal activity and with farmer operations (up to $1.409 \mathrm{mg}$ from 12.00 to 13.00 ), the increased activity induced the suspension of dust particles from the litter and its resuspension in the environment. 
- The high dust concentration of $\mathrm{PM}_{10}$, of fine particulate matter $\left(\mathrm{PM}_{2.5}\right)$ and its remarkable daily variation measured in the aviary system house are generally considered the primary source for respiratory affections and cardiac diseases, as heart attack and ischaemia, since every $0.01 \mathrm{mg}$ of dust concentration variation, the risk of mortality in people is increased for $6 \%$.

\section{Acknowledgements}

The authors would like to express appreciation for the cooperation of the farmers in collecting the data used in this study. Funding was provided by ISPRA (ex APAT, Italian Agency for Environmental Protection; Agenzia per la Protezione dell'Ambiente e per i Servizi Tecnici, Roma) for a research initiative into agricultural air quality and emission into atmosphere $\left(2^{\text {nd }}\right.$ year, Survey on Poultry Housing).

\section{References}

Balduzzi M., Effetti biologici del $\mathrm{PM}_{10}$ rilevanti per la salute dell'uomo. Annali Istituto Superiore Sanità, 2003, 39(3), 411-417.

Berckmans D., Vandenbroeck P. and Goedseels V., Sensor for continuous ventilation rate measurement in livestock buildings. Journal of Indoor Air, 1991, 3, 323-336.

Carpenter G.A., Dust in livestock buildings-review of some aspects. Journal of Agricultural Engineering Research, 1986, 33, 227-241.

Costa A. and Guarino M., Definition of yearly emission factor of dust and greenhouse gases through continuous measurements in swine husbandry. Atmospheric Environment, 2009, 43, 1548-1556. doi:10.1016/j.atmosenv.2008.11.009.

Costa A., Borgonovo F., Leroy T., Berckmans D., Guarino M., Dust concentration variation in a pig barn in relation to on-line monitored animal activity. Biosystems Engineering, 104: 118-124. DOI 10.1016/j.biosystemseng. 2009.05.009.

Costa A., Guarino M., Navarotto P., Savoini G., Berckmans D., Effects of corn milling type on physical characteristics and on dustiness of swine diets. Transactions of the ASABE, 2007, 50(5), 1759-1764.

EC, European Commission, Directorate-General JRC. July Integrated Prevention Pollution Control (IPCC) Reference Document on Best Available Techniques for Intensive Rearing of Poultry and Pigs (ILF- BREF). 2003.

ENEA. Rapporto finale sul progetto: Misure di concentrazioni di materiale $\mathrm{PM}_{10}$ e $\mathrm{PM}_{2.5}$ nell' aria ambiente dei ricoveri zootecnici (suinicoli ed avicoli) ed elaborazione dei risultati per la valutazione delle emissioni di particolato in relazione alle tecniche di abbattimento d'inquinanti atmosferici. 2002, Roma.

Fabbri C., Valli L., Guarino M., Costa A., Mazzotta V. Ammonia, methane, nitrous oxide, carbon dioxide and particulate matter emissions in two different buildings for laying hens. Biosystems Engineering, 2007, 97(4), 441455.
Ferin J., Oberdoster G., Penney D.P., Pulmonary retention of ultrafine and fine particles in rats. American Journal of Respiratory Cell and Molecular Biology, 1992, 6, 535-42.

Haeussermann A., Costa A., Aerts J.M., Hartung E., Jungbluth T., Guarino M., Berckmans D., Development of a dynamic model to predict $\mathrm{PM}_{10}$ emissions from swine houses. Journal of Environmental Quality, 2008, 37(2), 557-564.

IPCC (Intergovernmental Panel on Climate Change). Revised 1996 IPCC. Guidelines for National Greenhouse Gas Inventories. Reference manual, 1997, Paris, France.

IPCC. Report of the IPCC Expert Meeting on Emission Estimation of Aerosols Relevant to Climate Change. 2-4 May, Geneva, Switzerland, 34, 2005.

Janssen J. and Krause K.H., Messun and simulation von ammoniak koncentrationen in ställen. In: H. Döhler and H. van den Weghe, Editors, Ammoniak in der umwelt, KTBL-Schriften-Vertrieb im Landwirtschaftsverlag GmbH, 1990, 21.1-21.12, Münster-Hiltrup.

Lagorio S., Forastiere F., Pistelli R., Iavarone I., Fano V., Incalzi R., Basso S., Benedetto R., Della Corte Am., Fuso L., Maiolo C., Sammarro S., Serra M., Spadaro S., Tramaglino L., Cattani G., Stacchini G., Marconi A., Ziemacki G., Ostro B., Inquinamento atmosferico e funzionalità cardiaca e respiratoria in tre gruppi di pazienti. Annali Istituto Superiore Sanità, 2003, 39 (3), 395-404.

Liao C.M., Chen J.W., Huang M.Y., Chen J.S., Chang T.J., An inhalation dose model for assessing dust-borne Vocodor exposure from feeding in swine buildings. Transactions of the ASAE, 2001, 44(6), 1813-1824.

Parry R.R., Schlenker E.H. and Feistner R., Correlation of positive Farmer's Lung serologies, respiratory symptoms, and pulmonary function tests in non-smoking workers involved in confinement raising of livestock., American Review of Respiratory Disease, 1987, 135, A451.

Pedersen S., Time-based variation in airborne dust in respect to animal activity. In Proc. 4th Intl. Livestock Environment Symposium, St. Joseph, Mich.: ASAE, 1993, 718-725.

Rylander R., Lung diseases caused by organic dusts in the farm environment. American Journal industrial Medicine, 1986, 10, 221-227.

Scholtens R., Van 't Ooster A., Performance and accuracy of methods for measuring natural ventilation rates and ammonia emission from naturally ventilated livestock houses. In: XII CIGR World Congress on Agricultural Engineering, Vol. N.94-C-033, pp 13, Milano, Italy, 1994.

Takai H., Pedersen S., Johnsen J.O., Metz J.H.M., Groot Koerkamp P.W.G., Uenk G.H., Phillips V.R., Holden M.R, Sneath R.W, Short J.L., Concentrations and emissions of airborne dust in livestock buildings in northern Europe. Journal of Agricultural Engineering Research 1998, 70, 59-77.

Thelin A., Tegler O. and Rylander R., Lung reactions during poultry handling related to dust and bacterial endotoxin levels. European J. Respiratory Diseases, 1984, 65, 266-271.

Wang Z., Manninen P., Malmberg P., and Larsson K., Inhalation of swine-house dust increases the concentrations of interleukin-1 beta (IL-1beta) and interleukin-1 
receptor antagonist (IL-1ra) in peripheral blood. Respiratory medicine, 1998, 92, 1022-1027.

Wathes C.M., V.R. Phillips, M.R. Holden, R.W. Sneath, J. L. Short, R.P. White, J. Hartung, Seedorf J., Schroder M., Linkert K.H., Pedersen S., Takai H., Johnsen J. OGroot Koerkamp., P.W.G., Uenk G.H., Metz J.H.M., Hinz T., Caspary V., and Linke S., Emissions of aerial pollutants in livestock buildings in Northern europe: overview of a multinational project. Journal of Agricultural Engineering Research, 1998, 70, 3-9.

Zhao L., Lim T.T., Sun H., Diehl C.A., Particulate Matter Emissions from a Ohio Belt-Battery Layer Barn, 2005 ASAE Annual Meeting, Paper 054010, 2005.

\section{SUMMARY}

The aim of this study was to evaluate $\mathrm{PM}_{10}$ concentration in three different laying hens houses (traditional battery cages with aerated open manure storage, aviary system and vertical tiered cages with manure belts with forced air drying) and to evaluate particulate matter emission into atmosphere during one year of observation. Internal and external temperature and relative humidity, ventilation rate, $\mathrm{PM}_{10}$ concentration have been continuously monitored in order to evaluate particulate matter concentration changes during the day and the season and to define $\mathrm{PM}_{10}$ emission factors. $\mathrm{PM}_{10}$ concentration was corrected by gravimetric technique to lower measurements error. In the aviary system house, TSP and fine particulate matter (particles smaller than 2.5 micron) concentration was measured. Average yearly $\mathrm{PM}_{10}$ concentration was remarkably higher in the aviary system house with $0.215 \mathrm{mg} \mathrm{m}^{-3}$ vs $108 \mathrm{mg} \mathrm{m}^{-3}$ for the ventilated belt house and vs $0.094 \mathrm{mg} \mathrm{m}^{-3}$ for the traditional battery cages house.

In the Aviary system housing, TSP concentration was $0.444 \mathrm{mg} \mathrm{m}^{-3}$ and $\mathrm{PM}_{2.5}$ was $0.032 \mathrm{mg} \mathrm{m}^{-3}$, highlighting the existence of a severe working environment for men and animals.

Recorded values for $\mathrm{PM}_{10}$ emission were $0.433 \mathrm{mg}$ $\mathrm{h}^{-1}$ hen $^{-1}$ for battery cages housing type, $0.081 \mathrm{mg} \mathrm{h}^{-1}$ hen $^{-1}$ for ventilated belt cages house, values lower than those available in literature, while the aviary system housing type showed the highest $\mathrm{PM}_{10}$ emission (1.230 $\mathrm{mg} \mathrm{h}^{-1} \mathrm{hen}^{-1}$ ) with appreciable peaks during the morning, together with the increased animal activity and daily farmer operations, as feed administration, cleaning and droppings removal.

Keywords: laying hens, housing systems, $\mathrm{PM}_{10}$, continuous measurements, emission factors. 